\title{
FORD MADOX FORD'S ESSAY ON POETRY AND T.S.ELIOT'S THE WAST LAND
}

\author{
Sigrid Renaux \\ Universidade Federal do Paraná
}

\begin{abstract}
SUMMARY:
The aim of this article is to bring together Ford Madox Ford's essay "Impressionism - Some Speculations", published as a preface to his own Collected Poems (1911) and considered to be "one of the most important critical documents to have been written on modern verse", and T.S. Eliot's The Waste Land (1922), one of the most celebrated poems of the twentieth century. By comparing both texts, one becomes aware that Ford's esthetic principles become concretized in Eliot's poetry and in this way Ford, although considered a minor poet, has succeeded in his criticism to prognosticate some of the directions Eliot (and consequently a whole generation of poets influenced by him) would follow.
\end{abstract}

Ford's essay "Impressionism - Some Speculations", published originally as a preface to his own Collected Poems of 1911 and considered at that time to be "one of the most important critical documents to have been written on modern verse", as Ford's editor, Frank MacShane, affirms (p. 139), can be further highlighted if we juxtapose its main tenets to Eliot's diction and subject matter in The Wast Land ${ }^{2}$. In this way, if for Ford "one of the principal functions of criticism was to awaken the critical faculties others"3, MacShane's assertion that Ford has influenced Pound, the Imagist poets and several younger novelists like Hemingway, Faulkner and Joyce ( $p$. xiii) can be extended to include Eliot in it, and the importancce of this inclusion becomes even more significant if we remember that The Waste Land, published in 1922, has

1 MACshaNE, F., ed. Critical writings of Ford Madox Ford. Lincoln, University of Nebraska Press, 1967. p.139-52.

2 EIIOT, T.S. Selected poems. New York, Harcourt, Brace \& World, 1964, p.5174.

3 MACBHANE, p.xill. 
become one of the most celebrated poems in the twentieth century.

Although it is sometimes dangerous to speak of direct influence - as Ford mentions, "influences are queer things and there is no knowing when or where they may take you". - and Eliot's cultural background as seen in his poetry makes this assertion even riskier, nevertheless we hope that, by following Ford's essay and comparing some of his statements to quotations from The Waste Land, it will become evident that many of Eliot's themes and techniques were, if not anticipated by Ford, at least Ford and Eliot seem to have worked in the same direction.

The fact that we are limiting our observations to The Waste Land does not mean that other poems could not have been chosen for the same purpose - as Prufrock and Other Observations, coeval with Ford's essay but which "no one would publish"s. It does not mean either that Ford's essay will explain all sections of The Waste Land. It only means that we can have a better insight both into Ford and Eliot, by reading their texts together.

Ford's arguments can be grouped, for the purpose of clarity, into two sections: those related to form (language) and those related to content (subject matter). The first point Ford makes, in relation to language, is that, contrary to what happens in France, where even a literary poet can write in a language that "any hatter can use", or in Germany, where "the poet writes exactly as he speaks", in England there is "a literary jargon in which we must write" or "every word will swear"s. This opinion is aslo confirmed by Pound, who, in characteristic sardonic manner, called "the common verse of Britain from 1890 to 1910 " - as quoted by Hugh Kenner - "a horrible agglomerate compost, not minted, most of it not even baked, all legato, a doughy mess of third-hand Keats, Wordsworth, half-melted, lumpy." As a consequence, Ford goes on, by avoiding the use of certain words which do not fit the literary jargon, English poetry will be "lacking in some of its members"; as he exemplifies, "if we cannot use the word procession we are apt to be precluded from thinking about processions" and processions are "very much part of the gnat dance that modern life is." (p. 141).

Ford even goes so far, in relation to this first item, to affirm that, besides using the language of his own day, "a language clear enough for certain matters", he would even employ slang where slang is felicitous, and vulgarity where

4 MACSHANE. D.147.

5 KENNER: H. The Pound era. Berkeley. University of Cauforala Press, 1073, p.280.

b MACSHANE, p.141, 140.

7 KENNER, D.80. 
it seems to be the only weapon against dullness (p. 152). Of course Ford was not the first critic to be aware of this, for the Romantic poets (Keats, Coleridge, Alfred de Vigny) already manifested their interest "in the vernacular, in the homemade, in the idiosyncrasies of the local."8

Another point Ford makes in relation to language, and which complements the one above, is to get rid of the idea that, having read Tennyson, Swinburne, Browning and Pope, "all poets must of necessity write affectedly, at great length, with many superfluous words - that poetry, of necessity, was something boring and pretentious." Ford even suspects that poetry is little read nowadays as a consequence of that erroneous impression." Thus, if on the one hand Ford advocates the inclusion of everyday language, as part of modern life, on the other he is also aware that the stilted and the superfluous have to be removed, in order to transform English verse.

This does not mean that reading, or tradition, should be excluded, on the contrary. But their function differs, and this leads us into the second part of Ford's argument, the content of modern poetry: reading, for Ford, is "an experience that one should go through not in order to acquire imitative faculties but in order to find - oneself." (p. 151) In other words, modern poets should be able to transform the experience former writers have already recorded in their own writings; even more, for Ford there should be a juxtaposition of the traditional with the modern, because "such juxtapositions suggest emotions." (p. 145). As he further stresses, "let us do anything in the world that will widen our perceptions. We are the heirs of all the ages. But, in the end (...) the purpose of all these pleasant travails is the right appreciation of such facets of our own day as God will let us perceive." (p. 145). This avant-garde position that Ford advocates can, nevertheless, be wrongly interpreted by the modern reader, for, as Hugh Kenner comments, we are willing to feel that when a poet borrows from previous poets, his inspiration has failed, and we enjoy grumbling about a lack of poets. ${ }^{10}$ The past is necessary to give us the right perspective for the present, because though art "never improves", it retains its past "in awareness".

And it is in this line of argumentation that we reach Ford's prediction of what the modern poet should do, much in the same vein as Emerson, more than a century back, had predicted for the poet who should chant America:

8 KENNER. D.129.

8 MACSHANE, p.147.

10 KENNER, p.443.

11 KENNER. p. 369. 
Modern life is so extraordinary, so hazy, so tenuous, with still such definite and concrete spots in it, that I am forever on the look-out for some poet who shall render it with all its values. ${ }^{12}$

Which are these values? Not any longer "love", or "country lanes" or "the singing of birds", ${ }^{13}$ as the reader in the 1900's would say; the business of poetry for Ford "is not sentimentalism so much as the putting of certain realities in certain aspects", the real stuff of poetry of our day is "the Crowd" - "blindly looking for joy, or for that most pathetic of all things, the good time". - and its accompanying symbols: ash-buckets, orange peels, empty tins, anaemic shopgirls, pickpockets... (p. 142-3).

But if Ford has emphasized the need for a change in form and subject matter in order to revitalize English poetry, his most important statement in this essay, and which presents his argument in a nutshell, leaves, nevertheless, enough space for the poet to exert his own creativity, filtering form and content through his sensitivity. He starts by saying that

(...) for a quarter of a century, I have kept before me one unflinching aim - to register my own times in terms of my own time, and still more to urge those who are better poets and better prose-writers than myself to have the same aim. (p. 141)

But he adds, at the end of his essay, that "is is the duty of the poet to reflect his own day as it appears to him, as it has impressed itself upon him." (p. 150).

One does not have to go very far, nor very deep, into The Waste Land, to call to one's mind several passages in which Ford's tenets can be confirmed. Achually Eliot's words in "The Use of Poetry and the Use of Criticism", among other texts, confirm Ford's ideas also at the level of criticism, ("Poetry may effect revolutions in sensibility such as are periodically needed; may help to break up the conventional modes of perception and valuation which are perpetually forming, and make people see the world afresh, or some new part of it."14); and certain passages in Eliot's other poetry, as mentioned, present an almost literal analogue to Ford's words in this essay, such as his mentioning the shoulders of women in evening dress as an example of the crowd looking

14 ELIOT. T.8. The use of poetry and the use of criticism. London, 1933. p.155. Quoted bJ TRAVERSI. D. T.S.Eliot: the longer poems. London. Bodley Head. 1976. p.17. 
for Romance, and Prufrock soliloquizing "And I have known the arms already, known them all / Arms that are braceleted and white and bare (...) Arms that lie along a table, or wrap about a shawl". ${ }^{15}$ in his disillusioned love song.

But keeping to our aim to juxtapose passages from The Waste Land to Ford's arguments, let us mention first of all, in relation to subject matter, Eliot's Notes to the poem, in which he acknowledges that the title, plan and symbolism were suggested by Jessie L. Weston's book From Ritual to Romance, as aiso by Sir James Fraser's The Golden Bough. Both books corroborate Ford's assertion about reading and about our being the heirs of all the ages, besides providing The Waste Land, as Derek Traversi affirms, "with the equivalent of what Dante, Milton, and other traditional poets were able to derive from the accepted 'mythologies' of their own times". "Furthermore, it is already a commonplace to mention the specific quotations which Eliot annotated to each section of The Waste Land, and which range from The Bible, through Baudelaire, Dante, Shakspeare, Ovid, Buddha, to cite only a few. It is the way Eliot's sensibility has found to express modern life, by juxtaposing the ancient and the modern and thus making us aware of both. As F.O. Matthiessen comments, Eliot "can accomplish this double task of accurately recording what he has felt and perceived, and at the same time interpreting it, only if he grasps the similarity that often lies beneath contrasting appearances, and can thus emphasize the essential equivalence of seemingly different experiences". ${ }^{1 i}$ Thus what matters to us is how Eljot's sensibility has transformed his inherited tradition and the reflection of "his own day", as Ford emphasises, into something new and original.

If the province of The Waste Land is "the entire human race speaking, and in time as well as in space"18, one of the doors to enter the poem is through the very word "procession", reminding us how much Ford enjoyed Heine's "Denn nach Köln am Rheine /Geht die Procession...", and how much he considered them to "embrace the whole of humanity"10. For in Eliot's poem we have a procession of past and present images, a metaphorical procession, in which our modern world, or the Waste Land, is presented through multiple perspectives of different personas, while at the same time we have a literal procession traversing London Bridge:

15 ELIOT, Selected pooms, p.13.

18 TRAVERSI, p. 16.

17 MATTHIESBEN, F.o. The nchlevement of T.B.Eliot. In: COX, C.B. \& HINCHIPFE, A.P. ed. T.S.Eliot The Waste Land; a casebook. London, Macmllian. 1975. p.109.

18 KENNER, p.95.

19 MACBHANE, p.140, 141. 
Unreal City,

Under the brown fog of a winter dawn, A crowd flowed over London Bridge, so many,

I had not thought death had undone so many. Sighs, short and infrequent, were exhaled, And each man fixed his eyes before his feet. Flowed up the hill and down King William Street, (...

(1. 60-66)

The pathos of this scene, of this procession which Eliot places in the Inferno by quoting Dante, can be juxtaposed to another metaphorical procession of goodnights, in which one hears "the crowd", "blindly looking for the good time", saying empty goodnights to each other, and, as a crosscurrent traversing their meaninglessness, Ophelia's singing "Good night, sweet ladies." on her way to melancholy death by water:

Goonight Bill. Goonight Lou. Goonight May. Goonight. Ta ta. Goonight. Goonight.

Good night, ladies, good night, sweet ladies, good night, good night.

The procession is present again in Madame Sosostris's cards, when she sees "crowds of people, walking round in a ring". (1. 56), and it goes on, metaphorically, with the symbols of our modern civilization strewn in the waters of the river Thames, much as in the past it bore nymphs: "empty bottles, sandwich papers, $i$ Silk handkerchiefs, cardboard boxes, cigarette ends, Or other testimony of summer nights". (1.177-179). Their function is much the same as "the orange peels with their bright colors" representing the leftovers of a little party of the night before, as Ford exemplifies,, 20 , although, according to Hugh Kenner, "the river is not restored to a sixteenth-century purity because the debris of which it is now freed was not a sixteenth-century strewing of petals but a discarding of twentieth-century impedimenta." ${ }^{\prime \prime 1}$ Nevertheless, the point is clearly made how the whole of humanity seems to become embodied in these fragments moving along, either people or objects.

But the procession Eliot presents is not only seen from the distance, like the crowd traversing London Bridge, we also have close-up scenes, with the camera following each member of the crowd into his or her room. We can follow the typist. who 


\begin{abstract}
(...) home at teatime, clears her breakfast, lights her stove, and lays out food in tins.

Out of the window perilously spread

Her drying combinations touched by the sun's last rays, On the divan are piled (at night her bed)

Stockings, slippers, camisoles, and stays.
\end{abstract}

She reminds us of Ford's anaemic shopgirl, with bad teeth and cheap black frock, and she is as pathetic and a touching, exclaiming "Well now that's done: and I'm glad it's over." (1.212) after her lover, the young man carbuncular, has departed, as Ford's shopgirl. At the same time, the sonnet form diffused through the loveless sex experience the typist undergoes reminds us, according to Hugh Kenner, how Romeo and Juliet exchanged first kisses, ${ }^{22}$ in this way merging a contemporary and a literary love scene, through form and content, for if the sonnet from takes us back to Shakespeare, the language used employs slang and vulgarity, where necessary.

We can also follow other "heroines" in this procession of human fragments in the poem, such as the lady in "A Game of Chess" who complains of neglect, in a monologue that never becomes a dialogue:

\footnotetext{
"My nerves are bad to-night. Yes, bad. Stay with me. "Speak to me. Why do you never speak. Speak.

"What are you thinking of? What thinking? What? "I never know what you are thinking. Think."
}

This unidentified lady (who Hugh Kenner asserts carries overtones of Eliot's deranged wife Vivien), ${ }^{23}$ another close-up image detached from the procession, deflates with her everyday diction the long passage in elevated language which precedes her own words. This contamination that the quotations from Shakespeare, the Aeneid, Paradise Lost, the Metamorphoses suffer puts both texts in the right balance, for the art of the past is there, with its corresponding diction - but aware of it - while the present ordinariness, by this very juxtaposition, widens our perceptions as it suggests new and reminds us of old emotions.

The card of the drowned Phoenician Sailor is another recurring image in the poem, for he is seen again and again, as if "walking round in a ring": first in Madame Sosostri's cards, then transformed in Stetson ("You who were with me 
in the ships at Mylae!" 1. 70) on London Bridge, or again in the section "Death by Water", while the line "Those are pearls that were his eyes" (lines 49 and 125), from Ariel's song in The Tempest, which follows the presentation of the card is another transformation the drowned sailor has suffered. In relation to this passage Hugh Kenner confirms Ford's tenet of the poet's duty to reflect his own day as it has impressed itself upon him, when he says that

In the echo chamber, Tradition, one's words often pass through forms other men have used. Who is the poet? a medium? To some extent words use him; in his mind diverse things, linguistic included, are perpetually entering into new combinations. Sometimes, turning the tables, he can make words other men wrote sound like words he might have written himself."-

For Eliot, by making Shakespeare sound like himself, or like the persona who speaks the line in the poem, not only makes us share his disiocation in time and space but even his dislocation from one type of sign - the visual - through the card, to another type - the auditive - through the song, and the new combinations engendered are as redeeming as the transformation of "drowned" eyes into pearls.

The procession of past and present images reaches it end when, in section V, the "falling towers /Jerusalem Athens Alexandria/Vienna London/Unreal" (1. 374-77) suggest the collapse not only of London but of the whole of Western and Eastern civilizations, while the collapse of London Bridge "London Bridge is falling down falling down falling down" (1. 427) - stresses once more the disintegration of the crowd of people flowing over it. What is left over for the poet is language, in the form of fragments - "These fragments I have shored against my ruins" (1.431) - fragments of readings

Poi s'ascose nel foco che gli affina Quando fiam uti chelidon - I swallow swallow Le Prince d' Aquitaine à la tour abolie (...) Why then Ile fit you. Hieronymo's mad againe. (1.428-432)

and fragments of foreign prayers, forming a last metaphorical procession in which the inadequacy of Western response is emphasized by the fact that the three last words in English 
are from Kyd's Spanish Tragedy in which madness is emphasized.

In this way, Ford's assertions above that "the purpose of all these pleasant travails is the right appreciation of such facets of our own day as God will let us perceive", and that "it is the duty of the poet to reflect his own day as it appears to him", bring form and content together again as projected in the last eleven lines of the poem, where form is content and content is form, where the fragmentary structure of form and content corroborates the ruinous state of civilization as seen through Eliot's sensibility.

But Eliot also goes beyond Ford's expectations for the poet of his day and circumstance, by voicing not only "the life of dust, toil, discouragement, excitement and enervation" led by Ford and "many millions (...) today","2 but also by presenting redemption in the form of words from the Upanishad, "Datta, dayadhvam, damyata". The juxtaposition of these Eastern cultural parallels to our Western prayers "Give" reminding us of St. Francis' "it is by giving that we receive", "Sympathise" and "Control" reminding us of Our Lord's Prayer "as we forgive those who have sinned against us" and "let us not fall into temptation" - show us not only how both cultures can meet, but also how our debased and worn-out dialect can be purified again (using Mallarmé's phrase for Poe), through contact with equivalent foreign words.

In this way, as the aim of this study was to bring together Ford's tenets and Eliot's poetry, it is obvious that much of The Waste Land has been left out, either because by taking more examples we would be repeating Ford's arguments, or by the fact that many aspects of the poem are not covered by Ford's essay. Nevertheless, we hope our point has been made that Ford, although a minor poet, has succeeded in his criticism to prognosticate some of the directions modern poets would follow and how Eliot - the greatest poet of the Modern Age - has concretized these aims in The Waste Land.

\section{RESUMO:}

O objetivo deste trabalho é aproximar o ensaio de Ford Madox Ford "Impressionism - Some Speculations", publicado como prefácio de seus próprios Collected Poems (1911) e considerado como um dos mais importantes documentos críticos escritos sobre poesia moderna, e The Waste Land (1922) de T.S. Eliot, um dos mais famosos poemas do século XX. Comparando ambos os textos, per- 
cebe-se que os principios estéticos de Ford se concretizam na poesia de Eliot e que portanto Ford, apesar de consi. derado um poeta menor, conseguiu em sua crítica prognosticar alguns dos caminhos que Eliot - e consequientemente toda uma geração de poetas influenciados por ele - iria seguir.

\section{BIBLIOGRAPHICAL REFERENCES}

1 ELIOT, T.S. Selected Poems. New York, Harcourt; Brace \& World, 1964.

2 . The use of poetry and the use of criticism.

3 KENNER, H. The invisible poet. In: COX, C.B. \& HINCHLIFFE, A.P., ed. T.S. Eljot The Waste Land; a casebook. London, Macmillan, 1975. p. 168-99.

4 . The Pound era. Berkeley, University of California Press, 1973.

4 MACShANE, F., ed. Critical writings of Ford Madox Ford. Lincoln, University of Nebraska Press, 1967.

6 MATTHIESSEN, F.O. The achievement of T.S. Eliot. In: COX, C.B. \& HINCHLIFFE, A.P., ed. T S Eliot The Waste Land; a casebook. London, Macmillan, 1975. p. 108-27.

7 TRAVERSI, D. T.S. Eliot: the longer poems. London, Bodley Head, 1976. 